\title{
Unemployment and health: the quality of social support among residents in the Trent region of England
}

\author{
H Roberts, JCG Pearson, RJ Madeley, S Hanford, R Magowan
}

\begin{abstract}
Objective - To examine the quality of social support among unemployed residents in Trent, England.

Design - Secondary analysis of data generated by those of working age drawn from a postal lifestyle survey of the adult population of Trent region.

Subjects and setting - Subjects were 6987 individuals (males 16-64 years and females 16-59 years of age), of whom 9.9\% (689/ 6987) were unemployed.

Main outcome measures - Responses about the quality of social support obtained from three key questions.

Results - Generally, the unemployed reported poorer quality of social support than employed persons $(p<0.0001$ ) on all three key elements examined: $31 \%$ v $17 \%$ respectively had no practical support; $19 \%$ v $10 \%$ had no help with solving problems, and $21 \% \mathrm{v} 10 \%$ had no emotional support. Only $57 \%$ of the unemployed had all three of these elements compared with $75 \%$ of the employed. Unemployment and lack of social support had independent and deleterious effects on perceptions of general health and mental health. Relationships remained after allowing for the possible confounding effects of age, gender, and household composition.

Conclusions - There is a relationship between unemployment and poorer quality of social support which may help to explain some of the increased morbidity and mortality experienced by this group, especially that related to mental health.
\end{abstract}

( $\mathcal{F}$ Epidemiol Community Health 1997;51:41-45)

Department of Public Health Medicine and Epidemiology, University of

Nottingham Medical School, Nottingham NG7 2UH

H Roberts

JCG Pearson

RJ Madeley

$S$ Hanford

NHS Executive, Trent, Sheffield S10 3TH

R Magowan

Correspondence to: Dr H Roberts.

Accepted for publication June 1996

In recent years around 3 million people eligible for benefits have been registered as unemployed in the UK. However, the UK Government has frequently changed the method of calculating the level of unemployment since 1979 and pressure groups, such as the Unemployed Unit and the National Association of Local Government, have argued that the 'real' unemployment figure has been nearer 4 million. In 1994, when this study took place, 2.7 million people were officially unemployed being $11.6 \%$ of the economically active population of the UK. Since then unemployment has fallen slightly.

Studies consistently show strong relation- work, the threat of job loss, and unemployment itself and poorer health, ${ }^{1234}$ generating justifiable pleas for action. ${ }^{56}$ Unemployment is associated with poorer physical health, ${ }^{78}$ partly explained by evidence that those in poorer health are more likely to become unemployed and stay unemployed, ${ }^{9}$ less healthy lifestyles, ${ }^{10}$ and an increase in weight but not necessarily in alcohol and tobacco use ${ }^{11}$ and despite similar physical activity levels. ${ }^{12}$

In terms of mental health, a wide ranging review of the literature concluded that unemployment in itself can cause poor psychological health. ${ }^{13}$ When extreme, this increases the risk of, for example, psychiatric admission, ${ }^{14}$ parasuicide, ${ }^{15}$ and suicide. ${ }^{16}$ The detrimental impact of long term unemployment on family survival and family health is well documented. ${ }^{1718}$ The reasons for some of the relationships between unemployment and increased health risks are not clear but have an inter-relationship with risks also associated with poverty. ${ }^{56}$

It is well accepted that many environmental and individual characteristics interact to create social support systems at any one point in time that may have either a positive or detrimental impact on health. The precise impact on health of any complex dynamic factor, such as employment status, is not easy to quantify. Life problems, such as unemployment, rarely arise singly and each may make demands on different sources of support. As demand increases in complexity or intensity or continues over long periods, so support systems are less likely to be able to cope. ${ }^{19}$ Yet it is only in the last decade that overwhelming evidence has demonstrated that social factors influence both physical and mental health independently and in addition to well known behavioural risk factors. ${ }^{20212223}$

Social support may be measured in many ships between high levels of dissatisfaction with different ways. It has been argued that the perception of social support is more important than the reality of, for example, the reported number of contacts with others. ${ }^{24}$ However measured, recent and remarkably consistent patterns of findings about the impact of strong social support on health ${ }^{20}$ have shown a beneficial effect of strong social support, especially on mental health. Many point to the central role of spouses in providing social support. ${ }^{192526}$ Those in higher socioeconomic groups generally appear to report stronger social support, ${ }^{24}$ although relatively little detail is known about patterns in priority subgroups for health promotion, ${ }^{27}$ one of which is the unemployed. 
Table 1 Basic characteristics of employed and unemployed groups

\begin{tabular}{llll}
\hline & $\begin{array}{l}\text { Employed } \\
\text { No (\%) }\end{array}$ & $\begin{array}{l}\text { Unemployed } \\
\text { No (\%) }\end{array}$ & \\
\hline Gender: & & & \\
Male & $3190(50.7)$ & $508(73.7)$ & $\chi^{2}{ }_{1}=132, \mathrm{p}<0.00005$ \\
Female & $3108(49.3)$ & $181(26.3)$ & \\
Age (y): & $2411(38.3)$ & $295(42.8)$ & $\chi^{2}{ }_{2}=49, \mathrm{p}<0.00005$ \\
$\quad 16-34$ & $3234(51.3)$ & $273(39.6)$ & \\
$35-54$ & $653(10.4)$ & $121(17.6)$ & \\
$55+$ & $370(5.9)$ & $98(14.2)$ & $\chi^{2}{ }_{3}=70, \mathrm{p}<0.00005$ \\
Household: & $197(3.1)$ & $23(3.3)$ & \\
$\quad$ Alone & $5731(91.0)$ & $568(82.4)$ & \\
Children only & & & \\
Other adults & & & \\
\hline
\end{tabular}

This paper focuses on respondents' perceptions of three crucial qualities of social support. ${ }^{28}$ The study is based on secondary analyses of responses to three simple questions completed by economically active subjects (ie, those below retirement age ( $<65$ years for males and $<60$ years for females) who described their main occupation as working or unemployed or redundant (looking for work). Permanently sick and disabled people (unable to work), those looking after the home or family full-time, and students/trainees were excluded). Questions were integrated into a larger lifestyle survey. Inter-relationships between the perceived quality of social support, employment status, and some possible confounding factors are presented.

\section{Method}

SAMPLE

Data were obtained from the Trent health regional lifestyle survey which used a systematic sample of 18787 adults aged 16-70 years drawn from the eight family health services authorities' registers in Trent region, UK. The sample was stratified by district and six age and gender groups.

\section{DATA COLLECTION}

A self completion questionnaire about lifestyle was used which included questions about perceptions of the quality of social support derived from elsewhere. ${ }^{28}$ The wording of questions, requiring 'yes/no' responses, were:

- 'When I need extra help I can count on someone to help me, for example, with child care, shopping or transport

- 'I have someone I can count on when I need to talk over problems or make difficult decisions'

- 'There is someone I feel close to - someone I can share my feelings with'.

Because of the potentially sensitive nature of these questions respondents were instructed to answer only if they felt able to do so. The questions were shown to have substantial or moderate reliability on test/retest using the kappa statistic. (Excellent reliability was observed for other questions which were less subjective and answers less susceptible to change, such as smoking status, suggesting that real change in social support may have accounted for some of the apparent lack of congruity observed.)

Questionnaires were delivered by post during spring, 1994, and returned using business reply envelopes. Two reminders were sent to all outstanding respondents at 3-4 week intervals with the exception of males aged 16-34 years to whom three reminders were sent.

\section{RESPONSE}

Sixty six per cent $(11427 / 17430)$ of usable questionnaires were returned after exclusions (1357) caused by, for example, non-delivery. Compared to the study population, males, particularly young males, were slightly under-represented as were those in lower socioeconomic occupations and the unemployed. The response rate from economically active people could not be calculated as occupational and age specific data were not available from the sampling frame. Further details of method and response have been published elsewhere and findings complement those reported elsewhere. $^{29}$

\section{ANALYSIS}

Statistical analyses resulting in probabilities of $<0.05$ were taken as significant. Missing values were excluded from analyses. Analyses of each of three questions indicating presence or absence of each of the quality elements of social support included only those who gave definite answers. In the composite measure only those who answered all three questions were included.

Preliminary univariate analyses were carried out using $\chi^{2}$ to examine the relationship between unemployment and social support, and to investigate potential confounders. Multiple log-linear regression was used to adjust for the confounders, gender, age and household composition. Separate models were set up for each of the different aspects of social support, containing the unemployment variable and all of the confounders identified by the univariate analyses. In investigating the roles of unemployment and social support on general and mental health, the log-linear models contained the employment variable, social support summarised by the number of sources of support available, and the confounding variables of gender, age and household composition.

\section{Results}

A total of 6987 economically active individuals, of whom $689(9.9 \%)$ were unemployed, were identified. The unemployed group contained a higher proportion of males, more in the extreme age groups, and a higher proportion of people living alone (table 1).

Among the employed, more females than males worked in part-time occupations $-43 \%$ compared with $4 \%$. When allocated to manual or non-manual groups according to their current or most recent occupation, the unemployed were more likely to be in the manual group $-60 \%$ compared with $39 \%$ of the em- 
Table 2 Relationship of gender, age, household composition, and employment status to lack of quality in social support

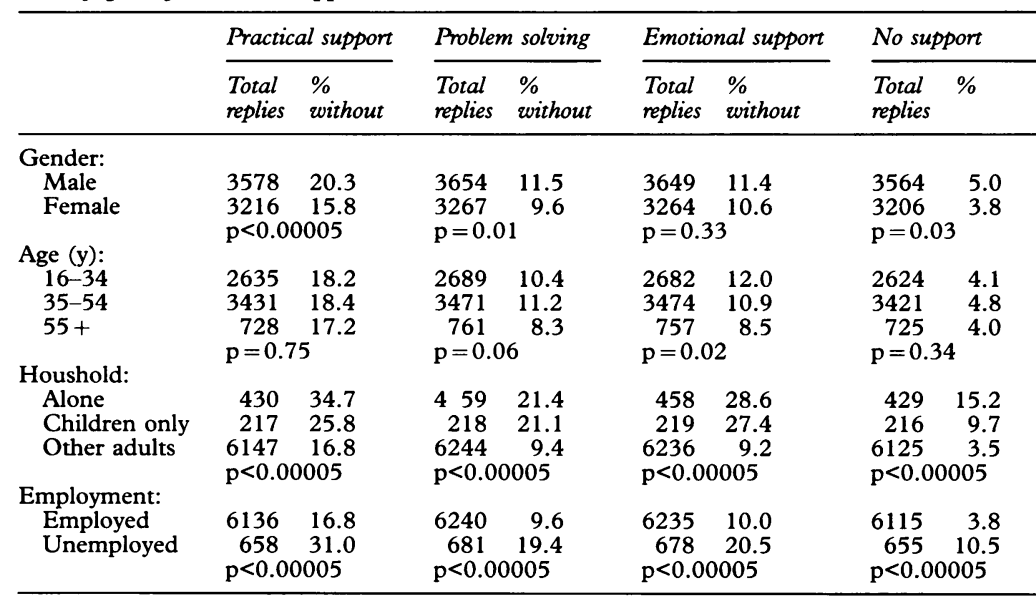

Table 3 Relationship of unemployment to quality of social support, adjusting for gender, age, and composition of household. Relationship expressed as rate ratios, with $95 \%$ confidence intervals (CI), calculated from multiple log-linear regression

\begin{tabular}{|c|c|c|c|c|}
\hline \multirow[b]{2}{*}{$\begin{array}{l}\text { Social } \\
\text { support }\end{array}$} & \multirow[b]{2}{*}{$\begin{array}{l}\text { Employment } \\
\text { status }\end{array}$} & \multirow[b]{2}{*}{$\begin{array}{l}\text { \% without } \\
\text { support }\end{array}$} & \multicolumn{2}{|c|}{ Rate ratios $(95 \% \mathrm{CI})$} \\
\hline & & & Crude & $\begin{array}{l}\text { Adjusted for gender } \\
\text { age and household }\end{array}$ \\
\hline Practical support & $\begin{array}{l}\text { Employed } \\
\text { Unemployed }\end{array}$ & $\begin{array}{l}16.8 \\
31.0\end{array}$ & $\begin{array}{l}1.9(1.6,2.1) \\
p<0.001\end{array}$ & $\begin{array}{l}1.7(1.4,1.9) \\
p<0.001\end{array}$ \\
\hline Problem solving & $\begin{array}{l}\text { Employed } \\
\text { Unemployed }\end{array}$ & $\begin{array}{r}9.6 \\
19.4\end{array}$ & $\begin{array}{l}2.0(1.7,2.4) \\
\mathrm{p}<0.001\end{array}$ & $\begin{array}{l}1.8(1.5,2.2) \\
\mathrm{p}<0.001\end{array}$ \\
\hline Emotional support & $\begin{array}{l}\text { Employed } \\
\text { Unemployed }\end{array}$ & $\begin{array}{l}10.0 \\
20.5\end{array}$ & $\begin{array}{l}2.1(1.7,2.5) \\
\mathrm{p}<0.001\end{array}$ & $\begin{array}{l}1.8(1.5,2.2) \\
\mathrm{p}<0.001\end{array}$ \\
\hline No sources of support & $\begin{array}{l}\text { Employed } \\
\text { Unemployed }\end{array}$ & $\begin{array}{r}3.8 \\
10.5\end{array}$ & $\begin{array}{l}2.8(2.2,3.6) \\
\mathrm{p}<0.001\end{array}$ & $\begin{array}{l}2.3(1.7,3.0) \\
\mathrm{p}<0.001\end{array}$ \\
\hline
\end{tabular}

Table 4 Relationships of unemployment and social support to perceived general and mental health presented as rate ratios, with $95 \%$ confidence intervals (CI), adjusted for gender, age, and household composition, and each other, using multiple log-linear regression

\begin{tabular}{|c|c|c|c|c|}
\hline \multirow{2}{*}{$\begin{array}{l}\text { Dependent } \\
\text { variable }\end{array}$} & \multirow[b]{2}{*}{ Predictor } & \multirow{2}{*}{$\begin{array}{l}\% \text { reporting } \\
\text { poor health }\end{array}$} & \multicolumn{2}{|c|}{ Rate ratios $(95 \%$ CI) } \\
\hline & & & Crude & Adjusted* \\
\hline General health & $\begin{array}{l}\text { Employment status: } \\
\text { Employed } \\
\text { Unemployed } \\
\text { No of sources of social } \\
3 \\
2 \\
1 \\
0\end{array}$ & $\begin{array}{l}9.6 \\
16.6 \\
\text { upport per unit: } \\
5.4 \\
8.3 \\
12.9 \\
16.9\end{array}$ & $\begin{array}{l}1.7(1.4,2.2) \\
\mathrm{p}<0.001 \\
1.5(1.4,1.6) \\
1.0 \\
1.5(1.4,1.6) \\
2.1(1.8,2.5) \\
3.1(2.5,4.0) \\
\mathrm{p}<0.001\end{array}$ & $\begin{array}{l}1.5(1.2,1.9) \\
\mathrm{p}<0.001 \\
1.4(1.3,1.6) \\
1.0 \\
1.4(1.3,1.6) \\
2.1(1.8,2.4) \\
3.0(2.3,3.8) \\
\mathrm{p}<0.001\end{array}$ \\
\hline Mental health & $\begin{array}{l}\text { Employment status: } \\
\text { Employed } \\
\text { Unemployed } \\
\text { No of sources of social } \\
3 \\
2 \\
1 \\
0\end{array}$ & $\begin{array}{l}21.9 \\
35.8 \\
\text { upport per unit: } \\
18.5 \\
28.9 \\
46.6 \\
57.6\end{array}$ & $\begin{array}{l}1.6(1.4,1.9) \\
\mathrm{p}<0.001 \\
1.5(1.4,1.6) \\
1.0 \\
1.5(1.4,1.6) \\
2.2(2.0,2.5) \\
3.4(2.9,3.9) \\
\mathrm{p}<0.001\end{array}$ & $\begin{array}{l}1.6(1.3,1.8) \\
\mathrm{p}<0.001 \\
1.46(1.39,1.53) \\
1.0 \\
1.46(1.39,1.53) \\
2.13(1.92,2.37) \\
3.11(2.66,3.65) \\
\mathrm{p}<0.001\end{array}$ \\
\hline
\end{tabular}

* Adjusted for gender, age and household, and each other.

ployed - although a further $10 \%$ of the unemployed and $2 \%$ of the employed gave inadequate or no information about occupation. For both males and females, a higher proportion of the unemployed came from the manual group when this could be determined from current or most recent occupation (males, $71 \%$ of unemployed compared with $46 \%$ of employed; females, $52 \%$ of unemployed compared with $33 \%$ of employed).
Social support was first investigated in terms of the basic characteristics of the groups (table 2). Gender was related to a lack of practical and problem solving support, and having no sources of support, with males reporting less social support in each case. The youngest age group, 16-34 years, reported less availability of emotional support than did the other age groups. Those subjects living in households without other adults reported lower levels of support for each of the measures.

For practical, problem solving and emotional support, the unemployed group had approximately double the percentage of persons reporting lack of support, and almost three times the percentage reporting no sources of support (table 2). Since the employed group was different in terms of the basic demographic characteristics which were related to lack of social support, multiple log-linear regression was used to investigate the relationship between unemployment and social support, adjusting for these potential confounding variables. After adjusting for gender, age, and household composition, the unemployed group still showed significantly less availability of support, with rate ratios just under 2 for the individual type of support and just over 2 for having no sources of support (table 3 ).

Finally the effects of unemployment on health were investigated. This investigation excluded all subjects who reported a long term disability or health problem affecting activity and work. Two measures of health were used, taken from the SF-36 questionnaire. ${ }^{30}$ For the question on perceived current general health, replies less than 'good' were taken to indicate 'poor general health'. Poor mental health' was defined from the SF-36 mental health scale as a score less than or equal to the population first quartile score of 60 .

The effects of unemployment and lack of social support were investigated separately and together, and adjusting for the potential confounding effects of gender, age, and household composition. Social support was measured in terms of the numbers of sources of support reported. Preliminary analyses indicated that the effect of this variable could be adequately described as a linear trend $\left(\chi_{1}^{2}\right.$ for trend $=77.2$, $\mathrm{p}<0.001$, and $\chi^{2}{ }_{2}$ for deviations from trend $=$ $0.2, \mathrm{p}=0.9$, for general health; $\chi^{2}{ }_{1}$ for trend $=$ 202, $\mathrm{p}<0.001$, and $\chi_{2}^{2}$ for deviations from trend $=3.1, \mathrm{p}=0.2$, for mental health).

Unemployment and lack of support both showed independent effects on perceived general and mental health after adjusting for gender, age and household composition (table 4). The unemployed were approximately 1.5 times more likely to report poor general health. Lack of a source of support also increased their risk of either type of poor health by approximately 1.5 times, with those reporting having no source of help being 3 times more likely to report poor health.

\section{Discussion}

Data from lifestyle postal surveys are particularly open to bias caused by non-response, 
and characteristically this is caused by poorer response by males, especially young males. Those in lower socioeconomic groups also tend to give lower measurements of some risk related behaviours than is true for the population as a whole. ${ }^{31}$ It is plausible that data here are also biased away from those with poorer social support, given the links between non-response patterns and, for example, males (with poorer practical and problem support) and younger people (with poorer emotional support). This non-response bias is likely to reduce the effects found rather than exacerbate them. On the other hand, data generally confirm known health-related risk and behaviour patterns associated with unemployment found in other studies, for example, higher smoking prevalence which has been reported elsewhere and from this study. ${ }^{29} 32$

It has been suggested that the more roles one fulfils the higher the likelihood of social support. ${ }^{24}$ It would therefore not be surprising if the nature and quality of roles outside work do not compensate for the removal an important aspect of most people's lives and the key finding here supports this view. They show convincingly that the unemployed perceive themselves to have poorer quality social support than those in employment. They are about twice as likely to report a lack of each type of support and all supports. Allowing for the confounding factors of age, gender, and household composition makes little difference to risk. Regardless of employment status, males are more likely to lack practical and problem solving support. This may be partly explained by the suggestion that generally women are more rooted in, and responsible for, what happens in the home and the community. ${ }^{33}$ Consequently they fulfil more roles of a different nature than men, thought to be important in enhancing social support. ${ }^{24}$ Thus the lack of access to or removal of some types of social support in the workplace may be less traumatic for women, possibly particularly when part-time work is undertaken. On the other hand, women do not appear to have enhanced access to emotional support, perhaps pointing to the crucial role of the family in providing this type of support to both women and men.

Access to a spouse is known to be key element in strong social support. ${ }^{1922425}$ It was predictable that those living without other adults would have poorer quality of support and that weaker emotional support would be reported by younger people, many of whom did not live with a partner and had perhaps not yet developed trusting, stable adult relationships. It may also be that young people's expectations of emotional support are higher. Living without other adults who can contribute complementary skills or on a low income could well result in lack of access to practical and/or problem solving support, such as obtaining or buying' child care or suitable transport. What was more unexpected was that known differences in social support patterns by gender and household composition did not overcome the influence of unemployment, which remained a strong independent influence. This may be attributable to the damaging stress on family relationships that unemployment causes..$^{131718}$

After the exclusion of those with long term illness or disability and allowing for other possible demographic confounders, the independent associations between unemployment, poor social support, and poorer perception of general and mental health remained. The unemployed were twice as likely to report poor mental health than poor physical health. Reviews of many other studies show that this is causal. ${ }^{37}$ The strong association between the poorest quartile of mental health scores and unemployment status was independent of other explanatory variables and tripled as the quality of social support weakened. Stress attributed to family tensions and financial worries are likely to have contributed to both poorer mental health scores and poorer social support. ${ }^{56171834}$

The perception of poorer general health may also be real, ${ }^{9}$ but based on less severe symptoms than those defined and excluded here. This is plausible, as among this sample and reported elsewhere ${ }^{3132}$ among the unemployed there is a higher prevalence of smoking and exposure to passive smoking and heavier consumption of alcohol. Anxiety over an increase in weight, observed among those moving into unemployment, ${ }^{11}$ may also contribute to poorer perceptions of general wellbeing, although in this study there is no evidence that more of the unemployed actually were overweight or obese according to a standard classification. ${ }^{35}$ It is not known whether individuals' perceptions of physical health changed after becoming unemployed or have remained constant through employment and unemployment.

It seems fair to conclude that the differences in the quality of social support presented in this paper help to explain at least some of the increase in morbidity, especially related to mental health, amongst the unemployed. However, the study does not establish whether the relationship is causal and nor does it demonstrate whether good quality social support acts as a buffer or protects against the impact of unemployment. What these data do show is that the field is worthy of further investigation. Longitudinal cohort studies are needed to examine how the threat of unemployment and actually becoming unemployed effects social support; whether disruption to social support caused by threat of job loss and job loss itself is ameliorated over time either during continued unemployment or re-employment and the impact of unemployment on social support within and provided to whole families when main breadwinners become unemployed. Qualitative studies should explore in more detail the nature of the practical, problem solving and emotional support that are lacking and whether these differ by employment status. Developing techniques by which to strengthen social support among the unemployed or those preparing to move into unemployment may, arguably, do as much to prevent ill health, if not more, than screening and other population health promotion strategies.

Thanks to Ms Regina Dengler, and to Trent Regional Health Authority (NHS Executive, Trent) for funding. 
1 Smith R. Unemployment: here we go again. $B M F$ 1991; 302:606-7.

2 Graetz B. Health consequences of employment and unemployment: longitudinal evidence for young men and women. Soc Sci Med 1993;36:715-24.

3 Wilson SH , Walker GM. Unemployment and Health: a review. Public Health 1993;107:153-62.

4 Ferrie JE, Shipley MJ, Marmot MG, Stansfield S, Smith GD. Health effects of anticipation of job change and non-employment: longitudinal data from the Whitehall II study. BMF 1995;311:126-9.

5 Benzeval M, Judge K, Whitehead M. Tackling inequalities in health. London: Kings Fund, 1995.

6 Laughlin S, Black D eds. Poverty and health. Tools for change. Birmingham: Public Health Trust, 1995.

7 Smith R. 'I'm just not right': the physical health of the unemployed. $B M F$ 1985;291:1626-9.

8 Iverson L, Sabroe S, Damsgaard MR. Hospital admissions before and after shipyard closure. BMF 1989;299:1073-6.

9 Elkeles T, Seifert W. Unemployment and health impairments. Eur f Public Health 1993;3:28-37.

10 Blaxter M. Health and lifestyles. London: Routledge and Keegan Paul, 1990.

11 Morris JK, Cook DG, Shaper AG. Non-employment and changes in smoking, drinking and body weight. $B M \mathcal{F} 1992$; 304:536-41.

12 Grayson JP. Health, physical activity level and employment status in Canada. Int $\mathcal{F}$ Health Services 1993;23:743-61.

13 Fryer D. Benefit agency? The Psychologist 1995;8:265-72

4 Kammerling RM, O'Connor S. Unemployment rate as a predictor of rate of psychiatric admission. BMF 1993;307: 1536-9.

15 Gunnell DJ, Peters TJ, Kammerling RM, Brooks J. Relation between parasuicide, suicide, psychiatric admissions, and socioeconomic deprivation. BMF 1995;311:226-30.

16 Pritchard A. Is there a link between suicide in young men and unemployment? Br f Psychiatry 1992;160:750-66.

17 Smith $R$. 'We get on each other's nerves': unemployment and the family. $B M \mathcal{F} 1985 ; 291: 1707-10$.

18 Seymour J. Give us a chance: child poverty and the health of the nation. London: Child Poverty Action Group with Health Visitors' Association, 1992.

19 Cohen S, Syme SL, eds. Social support and health. New York: Academic Press, 1985;43-60.
20 Badura B, Kickbusch I. Health promotion research : towards a new social epidemiology. WHO Regional Publications: a new social epidemiology. WHO Regional Publication

21 Marmot MG, Smith GD, Stansfeld S, et al. Health in equalities among British civil servants: the Whitehall I study. Lancet 1991;337:1387-93.

22 Turner JB, Kessler RC, House JS . Factors facilitating adjustment to unemployment: implications for intervention. American fournal of Community Psychology 1991; 19:521-42.

23 Hammer T. Unemployment and mental health among young people: a longitudinal study. Fournal of Adolescence 1993;16:407-20.

24 Turner RJ, Marino F. Social support and social structure: a descriptive epidemiology. F Health Soc Behav 1994;35: 193-212.

25 Antonovsky A. Unravelling the mystery of health. How people manage stress and stay well. San Francisco: Jossey Bass,

26 Dew MA, Bromet EJ, Penkower L. Mental health effects of job loss in women. Psychol Med 1992;22:751-64.

27 Bartley M. Unemployment and ill health: understanding the relationship. $\mathcal{F}$ Epidemiol Community Health 1994;48: 333-7.

28 Seeman TE, Berkman LF. Structural characteristics of social networks and their relationship with social support in the elderly: who provides support. Soc Sci Med 1988;26: 737-49.

29 Roberts H, Dengler R, Magowan R. Trent health adult lifestyle survey results, 1992-1994. Sheffield, UK: NHS Executive Trent, 1995.

30 Ware JE, CD Sherbourne. The MOS 36 item short-form health survey $(\mathrm{SF}-36) 1$. Conceptual framework and item selection. Med Care 1992;30:473-83.

31 Smith C, Nutbeam D. Assessing non-response bias: a casestudy from the 1985 Welsh Heart Health Survey. Health Education Research 1990;5:381-6.

32 Whitehead $M$. The health divide. London: Health Education Council, 1987 .

33 Orr J. Women's health in the community. Chichester: Wiley, 1987.

34 McAllister F ed. Marital breakdown and the health of the nation. 2nd ed. London: One plus One, 1993.

35 Nevill AM, Holder RL. Body mass index: a measure of fatness or leanness? Br f Nutrition 1995;73:507-16. 